小山 誠次

\title{
Kampo Formulas Containing Coicis Semen that are Effective in the Treatment of Verrucae
}

\author{
Seiji KOYAMA
}

M. D., Fushimi Clinic, 3-318 Ginza-cho, Fushimi-ku, Kyoto-shi, Kyoto 612, Japan

\begin{abstract}
Coicis Semen was known in ancient times as a medicine promoting longevity. In the 'Huang ti nei ching su wên', there is a reference to Coicis Semen in a description of one of the pulses (cardiac pulse without stomachic energy), and it is contained in four formulas in the 'Chin kuei yao lueh'. As for the effectiveness of Coicis Semen for the treatment of verrucae, there are no references in the 'Ben cao gang mu' or the 'Nodoku'. In the Edo period, a common treatment for warts was moxibustion. The first text thought to mention Coicis Semen for the treatment of verrucae was the 'Yamato Honzo. However, it is difficult to tell from the description of the condition whether it is in fact warts or not. Previously, the references contained in the later texts, 'Matsukageidan'and 'Seinosatan', containing a verruca formula (Chiyushimpo), have been considered to be theearliest notations of applying formulas containing Coicis Semen for the treatment of warts. However, independent investigation revealed the presence of a formula for verrucae in the text 'Meikahosen', compiled by Yamada Genrin twenty years before the 'Seinosatan'. The description in the 'Meikahosen' says 'Formula for warts: Coicis Semen-3 sen; Glycyrrhizae Radix-1 bu to beused not only internally but externally as well.

The realization of the ability of Coicis Semen to cure warts was thought to have occurred with the observation of many cases of remarkable effectiveness seen when large quantities were consumed in the form of rice and gruel containing Coicis Semen, rather than in the form of sweets made from what was called 'Chosenmugi or Coix lacryma-jobi L. var. koreana.

Key words: Coicis Semen, formulas effective for verrucae, 'Seinosatan', 'Meikahosen', Coicis Semen gruel.
\end{abstract}

Nihon Toyo Igaku Zasshi (Japanese Journal of Oriental Medicine), 47, 63-69, 1996 (accepted 28 Dec, 1995)

\section{緒 言}

薏蔌仁はハトムギ Coix lacryma-jobi L. var. ma-yuen STAPF の種子で, 薬用には包鞘付さの
まま，るいは脱穀して精白したもの，あるいは 更に粉末化して用いられる。

意莰仁の形態は同属のジュズダマCoix lacryma-jobi L. に似て, 『黄帝内経素問』第

医，伏見診療所，京都， $=612$ 伏見区銀座町3-318

[1995年12月28日受理] 
六巻・玉機真蔵論篇第十九に，「真心脉至堅而搏 如循意莰子累累然色赤黒不沢毛折乃死（原文訓 読 : 真心ノ脉ノ至ルコト堅ニシテ搏チ薏蔌子ョ循 ルガ如ク累累然トシテ色赤黒ニシテ沢カラズ毛折 テ乃チ死ス)」とあって, 堅くてコロコロしてい る様子を伝えている。

処方としては『金匱要略』2巻之上・痤湿暍病脉 証治第二に，「病者一身尽疼，発熱日晡所劇者， 名風湿, 此病, 傷於汗出当風, 或久傷取冷所致 也, 可与麻黄杏仁薏莰甘草湯」とあり, 肺瘘肺㿑 欬嗽上気病脉証治第七に, 「千金莘茎湯, 治郊有 微熱, 煩満, 胸中甲錯, 是為肺㿑」とあり, 胸㽻 心痛短気病脉証治第九に, 「胸痺緩急者, 意苡附 子散主之」とあって, 更に巻之中・瘡痽腸癱浸淫 病脉証并治第十八には, 「腸痽之為病, 其身甲 錯, 腹皮急, 按之濡如腫状, 腹無積聚, 身無熱, 脉数, 此為腸内有㖁膿, 㝨莰附子敗醬散主之」と ある。これらは薏荝仁が往古より生薬として用い られて来た歴史を物語っている。

今回, 往古より用いられて来た効能を踏まえた 上で, 治病作用に関して過去の文献的記載を改め て検討した。

\section{本 論}

\section{I 薏实仁の効能}

萻莰仁の効能については, 『本草綱目』 $\rrbracket^{3)}$ 第二十 三巻・薏茨仁の項に，「国治筋急拘攣不可屈伸久 風湿疾下気久服軽身益気。本経。除筋骨中邪気不 仁利腸胃消水腫令人能食。別録。炊饭作麥食主不 饑温気煮飲止消渇殺蚘蟲。蔵器。治肺瘘肺気積膿 血刻嗽涕唾上気煎服破毒腫。甄権。去乾湿脚気大 験。孟詵。健脾益胃補肺清熱去風勝湿炊飯食治冷 気煎飲利小便熱淋。時珍」とあって, 「神農本草 経」では上薬に分類され, 軽身益気，不老延年の 薬だったことを物語っている。いずれにしても治 病作用は記載されていない。

また，『能毒』゙ 上・薏の項に，「筋急二拘攣ニ 能進食下気乾湿脚気二虫二因寒筋急二八中焦極 冷二八薏蔌仁也性微寒也。筇急拘攣此薏蔌八筋, 攣二使薬ゾ拘ハカフハル攣ハヒキッル也。能進食 ト八脾胃ノ熱故ノ不食二也ヒヘタニ八悪シ。乾湿
脚気卜八斡ホソルル也脚気二八当帰地黄卜使也 あって,やはり治病作用は記載されていない。

更に, 『妙薬単方』 $\rrbracket^{55}$ に薏苫仁の咽喉腫痛に対 する効能は記載されているが，治病作用について は同様に触れられていない。この『妙薬単方』の 用法は, 『外台秘要方』 $\rrbracket^{(2)}$ 巻第二十三・咽喉腫方五 首から引用したものであろう。

\section{II 治疮療法}

一方, 疮贅の治療法としては, 『外科枢要』》 三・疫の項に,「疫属肝胆少陽経風熱血燥或怒動 肝火或肝客淫気所致蓋肝熱水涸腎気不栄故精亡而 筋卛也宜以地黄丸滋腎水以生肝血為善若用蛛絲縓 螳螂蝕著艾尒必多致誤大抵此症与血燥結核相同故 外用腐蝕等法内服燥血消毒則精血愈虚肝筋受傷瘡 口翻突開張卒成敗症（筆者訓読 : 疮八肝胆少陽経 ノ風熱血燥二属ス或八怒り肝火习動ジ或八肝淫気 ア客シテ致ス所ナリ蓋シ肝熱スレバ水涸レ腎気栄 エザル故ニ精亡クナリテ筋攣キツル也宜シク地黄

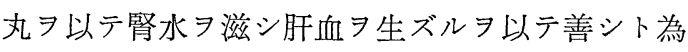
スベシ若シ蛛絲縓螳螄蝕著シキョ用テ艾众スレバ 必ズ多ク誤り 致ス大抵此症血燥ノ結核卜相同ジ 故二外腐蝕等ノ法 $习$ 用七内燥血消毒 7 服スレバ則 チ精血急々虚シ肝筋傷 受ケ瘡口翻リ突キデテ開 張シ卒二敗症ト成ル)」とあって, 地黄丸を以っ て腎水を滋し, 肝血を生じさせる治療法を指示 し, むやみやたらに艾炎療法を用いないよういさ めている。

しかし, 江戸初期の『病名彙解』8) 巻之六には, 「疥瘡 俗ニ云イボナリ……宜ク初テ起ルモノニ 艾众スレバ余八皆落ツ神効アリ又肬ト云リ」とあ って, こちらは逆に疮贅に対する艾众療法を推奖 している。な和，艾炎療法は今日でもよく行われ ている。

\section{III『大和本草』}

さて，一般には意荝仁の治病作用を最初に記載 した文献は『大和本草』であるとされている。

『大和本草』9) 巻之四・薏莰仁の項には，「….. $\bigcirc$ 湿ニ中リテ面二小瘡出テ恰如瀨二薏药仁 7 煎服 久有効此方本草二不載居家必用二云其苗堪為薪 今案ニ子 7 取テ食トシ薬トシ葉 7 煎シテノム其茎 ヨ薪トシ籬トスヘシ其根八去蚘蟲治牙痛亦堪為薬 
可謂益人多」とある。「湿ニ中リテ」は発症契機 を述べたものであり，「面二小瘡出テ恰如顀」が顔 面の多発性病贅を述べたものと解釈されている。

しかし，「面二小瘡出テ恰如瀬」だけではこの 病変が疮贅であるのかどうか判断し得ない。当時 既に, イボ, 痰, 肬, 疥瘡, 疾子等の用語はよく 知られていたはずであり, 疣贅であれば,なぜこ れらの用語を用いなかったか些か疑念を抱かざる を得ないからである。ただ結果的には薏荝仁の煎 服が有効であったような病変であることは間違い ないだろう。

むしろ逆に, 当時既に薏茨仁の外湿, 内湿に対 する効能は周知されていたことから，「面二小瘡 出テ恰如瀬」に対する薏莒仁の有効性を外湿環境 と関連付けたのであろら。そのため, 外湿に対す る本治療法を行ならことにより，「面二小瘡出テ 恰如䫅」に対する標治療法も奏功したと判断した のではないだろらか。この点は考按でも検討す る。

\section{IV『大和本草』以後}

『大和本草』以後の治病療法と薏莰仁の用途飞 ついて検討する。

『大和本草』刊の 4 年後に『和漢三才図会』が 発刊された。『和漢三才図会』年巻第十・人倫之 用には，「肬……疮同 和名以比保……釈名云肬 丘也出皮上聚高如地之有丘也 $\triangle$ 桉肬黒子共有二 種大如小豆而肌色高起一種如茄実匾不起並有母肬 生数子也以薬及众治其母則悉治或用胡麻花頻摺之 或用生茄子肉摺亦佳 (原文訓読 : 肬……㽼同 シ

和名八以比保……釈名二云フ肬八丘也皮ノ上二出 テ聚リテ高ク地ノ丘有ルガ如シ $\triangle$ 桉ズルニ肬黒 子共二二種有り大キサ小豆ノ如ニシテ肌色高ク起 ル一種八茄実ノ如ク匾ク起ラズ並二母肬有りテ数 子ヨ生ズ薬及ビ众 或八胡麻ノ花 ノ肉用ヒテ摺ルモ亦佳シ)」とあるが，「以薬及 众」の薬が何を指すのか不明である。

また更に，その 2 年後に発刊された『合類広益 霊宝薬性能毒大成』』始め, 『巻懐食鏡』 ${ }^{12)}$, 『用薬須知』 ${ }^{13)}$, 『薬籠本草』 ${ }^{14)}, 『 一$ 一本堂薬選』 ${ }^{15)}$, 『薬徴』16) 等々にはいずれも意莰仁の記載はある
ものの, 治疣作用は記されていない。

ただ『用薬須知』 ${ }^{13)}$ 巻之二・草部に䄧いて，「薏 莫仁 三種アリ和名唐麦ト云モノ真ナリ皮ヤワラ カニシテ色白肉厚ク粒大ナルモノ野生ノモノ八皆 非真其名川穀トモ贑珠トモ云つ念珠二作テ小児, 兓戯トス。下品ナリ乏キ時八可通用」とあり, 他 書が 2 種に分類しているのに，自信に満らた文勢 で 3 種に分類しているのは特異である。

歴史的にジュズダマ属の分類については，『八 トムギの効用』17)・第 5 章 日本に拈けるジュズ ダマ属の歴史に詳述されているが，最も多い場合 は 5 種に分類されたこともあったと述べ，これは 不当である旨，記されている。この意味からすれ ば,「神農本草経」を始め, 『黄帝内経 素問』,

『金實要略』等に記載されている薏苡仁の基源植 物が何であるかは推測の域を出ないと言わざるを 得ない。

疮贅の治療法としてはその他に, 『医療手引草』 18)別録下・外科の諸瘡の項に，「痒子の抜薬 天 南星ヨ末シ米ノ酢ニテトキ貼ル 又方 イワシ草 ノ汁ヨ貼クベシ○イワシ草八田ノ中ニアリ一寸ホ ドノ長サナリ薬八菲葉ノ如キモノナリ」の記載が ある。

一般的に民間薬による疮贅の治療薬として『漢 方と民間薬百科』19 に，アオギリ，アカザ，イチ ジク，エビズル，クサノオウ，コンニャク，スベ リヒニ, ソクズ, タンポポ, テンナンショウ，ナ ス，ナメクジ，ハトムギ，ホオズキ等々が記載さ れていて，今日でも民間薬的には利用されてい る。

\section{V『青囊頊探』}

さて，『大和本草』では薏莰仁を用いた病変が 記述的に明確でないことは既に述べたが，文献 上, 薏莰仁の治病作用として明確に記載された最 初のものが『増訂和漢薬考』20) に記載されてい る。そこでは寺尾国平が『臨休薬石新報』21) 第一 巻第十一号に発表した論文「薏莰仁の治病作用」 を引用して，『青囊頊探』とある。また『ハトム ギの効用』22)では『松蔭医談』, 『青囊頊探』とあ り，ヨクイニンェキス錠(散)を薬価収載している 小太郎漢方製薬の MEDICAL INFORMATION 


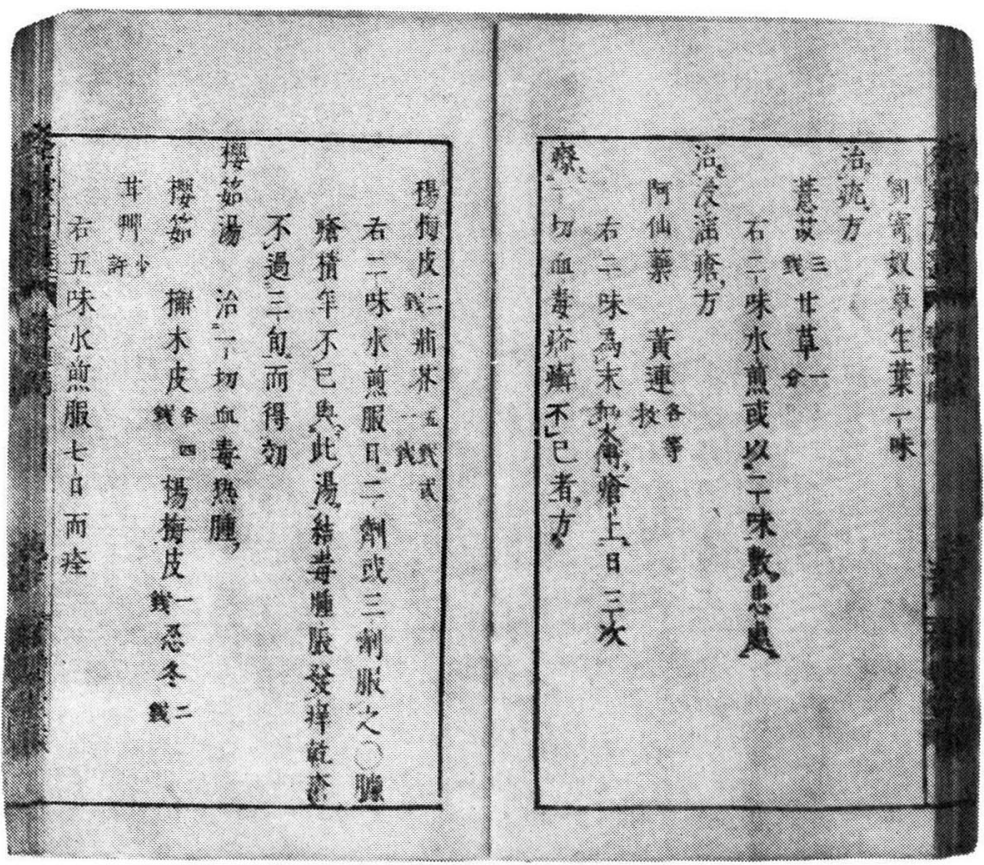

写真 1

にも『青囊頊探』とある。特に『青囊临探』23) 下 巻には有名な治疮神方の一項が設けられて拈り, 薏莰仁の治疮処方は『青囊頊探』をもって葶矢と なすと考兄られて来た。

先ず『松蔭医談』24)には，「いほの多く出たる に，薏荝子をあたふれば，しるしあり，肩ひだの いたみ，なべてのふき出ものにも，これを，もち ひて，しるしありといふことは，たしかにこ〉 ろみ得たるゆへ，いくその人に，かたりぬれど， あまりに無味なるものゆへにや，らけかは炡，人 打活し」とある。これは確かに疮贅に対して意茨 皇を投与したとの記載であり，『大和本草』と異 なり，明確な記述である。

次に, 『青囊頊探』23) 下巻・治肬神方には,「疫 雖是小恙, 至其蔓延, 則雖容顔如毛嬙西施, 亦有 其䫏醜（言極醜）似無塩女子焉，是以 録 経 験 数 万, 使閤中患之者得歓心矣, 治状神方, 屢試験, 虵蛻不以多少, 滚湯浸頻浣患処, 則疹○方, 治 疮蔓延者, 以活蛞蝓一箇, 転擦疮母上, 着粘訅乃 放棄, 則其疫自脱, 其他子疣尋急 $\bigcirc$ 又方, 意药仁 二銭, 甘草一銭, 以水一亚半, 煎取一薔温服, 四
五日而犹如払，（一方無甘草，用大腹皮亦妙，） ○方, 将获苓三銭, 水煎温服, 数日而自痊」と ある。この記載は意蔌仁による最初の治疫処方と されて来た。な拉，虵蛻は蛇の脱殸のことであ り，活蛞蝓は生さたなめくじのことである。

『松蔭医談』は寬政元年（1789）の序文があり， 寬政十一年（1799）に刊行された。また『青囊頊 探』には享和元年（1801）の序文がある。

\section{VI 『名家方選』}

しかしながら，今回独自の調査によって，山田 元倫撰『名家方選』25) ・瘡腫病の雑瘡に, 「治疮 方 薏药三銭甘草一分 右二味水煎或以二味敷患 処」との記載を見出した。これは内服のみならず 外用の用法をも記したものである。ここにその記 載箇所を写真 1 として供覧する。

『名家方選』は安永九年（1780）の序文があり， 装天明元年 (1781) の刊行である。それ故, 『青 襄頊探』よりも20年早く刊行されているので, 治 疮処方の歴史は 20 年遡及することになる。正に 『名家方選』をもって治疮処方の嗃矢たりらるこ とになる。 


\section{考 按}

薏莰仁の治病作用は，ではどのよらにして発見 されたのであろらか。

『原色和漢薬図鑑』26（上）・意药仁川穀の項 では, ジュズダマ属植物は八トムギとジュズダマ の 2 種が記されている。しかし『ハトムギの効 用』 17$)$ では, 明治以前の我が国のジュズダマ属植 物を文献学的に 4 種に分け，今日のハトムギを，

a) シコクムギ，トウムギと，b）チョウセンム ギに分類し，今日のジュズダマを，c）ジュズダ マと，d）オニジュズダマに分類している。

食用種に限ると，a）シコクムギ，トウムギは 『本草綱目啓蒙』27) 巻之十九・穀之二の意药仁の 項に，「真八意荝八享保年中二渡ル」とあるの で，少なくとも『大和本草』，『和漢三才図会』以 後渡来したことになり，また渡来後，『名家方選』 までほぼ50年間の期間があることになる。なお，

『本草綱目啓蒙』27) の同箇所には，「一種トウム ギ,一名朝鮮ムギ」とあって， b ）チョウセンム ギと同一植物としてトウムギを充てている。この b ）チョウセンムギは，『ハトムギの効用』17に よれば，「加藤清正が，朝鮮から持ち帰ったもの と推察する」とあるので，少なくとも江戸初期に は知られていたことになる。また「トウムギとチ ヨウセンムギは，きわめて近似の植物である」た め,「ハトムギは, 食用種 2 種を総括した名称で あることは，明治10年代の文献によってあきらか である」ことにもなる。

そこで, 元禄十年初版の『農業全書』28) 巻之

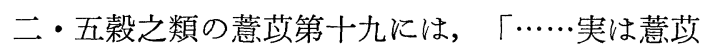
仁と云薬種なり。性のよき物なり。病人の食物に 調て用ゆべし。粥になり。飯に交へ。だんごにし た〉め。様々料理多し。……とあり, 更に『和 漢三才図会』299 巻第百三・穀類の薏荝仁の項に は, 「……或炊飯食気味如麦飯或粗末同粳米煮粥 食共有益（原文訓読：……或八飯二炊テ食フ気味 麦飯ノ如シ或ハ粗ク未二シテ粳米ト同ク粥二煮テ 食フ共二益有リ）」とあるので，このb）チョウ センムギが食用として利用されて来たものと思わ れる。
更には，寛永二十年に成書した『料理物語』 30)・第十八 菓子の部には，「括こし米よくい にんをよくほし。引わり米のごとくにしてきつ称 色にいり。さてさとうに水をくはへふかせ。に党 候時かさにすこしつうっさたらをとりわけ。よくい をすこしづ〉入まぜ。盆へあげ候へば。かたまり 候がよさかげんなり。いくたびにもかさにとりわ けつかまつりてよし。道明寺にてもいたし候」, 及び「近衛様雪餅 白术。二両。获苓。一両。山 薬。二両。蓮肉。二両。よくいにん。二両。右よ くこにしてうるの米四分。もち六分の粉に合す り。さたら八両。右何もよくかきあはせ。つねの ことく布をしき。むし候てきり出し候也。無比類 也」とあって，薏药仁が菓子としても利用されて いたことを表わしている。この薏荝仁も上記の事 情により恐らく， b ）チョウセンムギであろらと 思われる。

このように，薏莒仁は一方では粥などの食料と して, また一方では菓子の材料として食用に供さ れていた。

ここでもし，病贅に罹患した人が薏荝飯や薏蔌 粥として摂取すればどらなるであろらか。また実 際そらであったよらに，特に飢飳に際して他に摂 食するものがそしければ，非常に治病的に奏効し たであろう。これは容易に想像しえる。

『本草衍義補遺』31) の薏荝仁の項にも，「…… 用之須倍於他薬, 此物力勢和緩, 須倍用即見効。 ……とある。すなわち, 菓子類に含有される程 度の分量では治病効果の点で明白でなくとも, 薏 荝飯や薏莰粥ともなればはるかに大量に摂取する ことになり，今日でいう著効例を多数経験するこ とになったはずである。そしてこれらの貴重な経 験を踏をえて，『名家方選』の治病方となったの であろう。同様にして『大和本草』の記載におい ても，薏药仁によって治癒したという事実が先に あり，その理由付けとして当時既によく知られて いた湿に対する効能を引き出し，「湿ニ中リテ」 となったのではないかと思われる。

以上の大量摂取と軌を一にして, 筆者もヨクイ ニンェキス錠（散）を処方するときは，以前から 可及的多量投与を心が忷ている。 
最後に，『世医得効方』 ${ }^{322}$ 巻第四 - 大方脉雑医 科諸痺には，「薏莰粥治久風湿痺。補正気。除 胸中邪気。利腸胃。消水腫。久服軽身益気。薏药 仁一升為末。以水作砩。空心服」とあるが, 残念 ながら中国では意荝仁の治疮作用は発見されなか った。

以上をまとめると，食用種であるチョウセンム ギが加藤清正によって持ら帰られ，一方では粥な どの食料として，また一方では菓子の材料として 食用に供されていた。特に薏药飯や薏药粥では大 量に意莰仁を摂取することになるので，疫贅に罹 患した人が摂食すれば著効例を多々経験したはず である。これらの貴重な経験を累積し, 『名家方 選』の治疮方となったのであろう。また同様の類 推から『大和本草』の記述が疮贅ではないにして も, 結果的に治癒したという事実から薏䓍仁の湿 に対する効能を引き出して記したものではないだ ららか。

\section{結 論}

薏莰仁の治病処方は山田元倫撰『名家方選』を もって蒿矢となす。

付記『黄帝内経素問』『妙薬単方』『用薬須知』『本 草綱目啓蒙』『農業全書』『料理物語』は杏雨書屋所 蔵, 『医療手引草』は聖光園細野診療所所蔵。いずれ も同文献の閲覧に対しまして深謝致します。また『八 トムギの効用』は小太郎漢方製薬所蔵で, コピーによ る同文献の提供に対しまして深謝致します。更に『臨 床薬石新報』は京都府立医科大学図書室所蔵で, 同文 献のコピーサービスに対しましても感謝致します。

本論文の要旨は第46回日本東洋医学会学術総会 (平 成 7 年 6 月 9 日〜 11日，金沢）飞执いて発表した。

\section{文 献}

1) 吳峜注: 黄帝内経素問, 第六巻, 九丁表, 出雲寺 和泉掾，宝永三年

2) 張仲景著: 新編金買要略方論, 卷之上, 七丁表, 二十八丁表一裏, 三十一丁表一裏, 巻之中, 三十 一丁裏, 出雲寺松栢堂, 享和元年

3）李時珍撰: 新板校正本草綱目, 第二十三巻, 十八 丁裏一十九丁表, 発刊者不明, 江戸後期和刻

4) 曲直瀬道三述, 曲直瀬玄朔校録 : 能毒, 上, 三十
八丁裏一三十九丁表，村上平楽寺，正保二年

5 ) 穂積甫庵著 : 妙薬単方, 三十三丁裏, 書堂松雲斎 他, 元禄七年

6) 王善著 : 外台秘要 (復刻) 上冊, p.629, 国立中 国医薬研究所, 1964

7) 薛己撰 : 外科枢要, 三/薛氏医案, 一/四庫医学 叢書, p.763-356, 上海古籍出版社, 1991

8) 蘆川桂洲著 : 病名菓解, 巻之六, 十八丁裏, 植村 藤右衛門, 貞享三年

9 ）貝原益軒編録：大倭本草，巻之四，十四丁表，小 野善助，宝永六年

10）寺島良安編: 和漢三才図会（復刻), p.150, 吉川 弘文館, 1906

11）三村玄碩編著 : 合類広益霊宝薬性 能 毒 大成, 巻 三，三丁表一四丁表，土川字平他，正徳五年

12）香月牛山著: 巻懷食鏡, 七丁表一裏, 茨城多左衛 門他, 明和三年

13）松岡玄達編 : 用薬須知, 巻之二, 十二丁裏, 野田 藤八，享保十一年

14）香月牛山著, 難波恒雄編 : 薬籠本草/香月牛山選 集, 二, pp.361-364, 漢方文献刊行会, 1974

15）香川修庵著：一本堂薬選，中編，七十二丁表，文 泉堂, 享保十六年

16）吉益東洞著 : 薬徴, 巻之下, 五丁裏一六丁裏, 出 雲寺文治郎他，文化九年

17）古川瑞昌著：ハトムギの効用一ガンと美容と長寿 にきく一, pp.30-45, 六月社, 1963

18）加藤謙斎撰：医療手引草，別録下，外科，三十一 丁裏一三十二丁表, 浅野弥兵衛, 明和三年一天明 四年

19）大塚敬節著：漢方と民間薬百科／改訂增補, pp.88-89, p.91, p.109, p.126, p.171, p.191, p.220, p.228, p.239, p.246, p.254, p.256, p.278, p.294，主婦の友社， 1978

20）小泉栄次郎編：増訂和漢薬考, 前編, pp.338-339, 朝香屋書店, 1925

21）寺尾国平 : 意莰仁の治㾌作用, 臨床薬石新報, 第 一巻, 第十一号, p.504, 1906

22）古川瑞昌著：ハトムギの効用一ガンと美容と長寿 飞きく一, p.89, 六月社, 1963

23）片倉鶴陵著：青囊瑣探，下巻，二丁裏一三丁表， 勝村治右衛門他, 享和元年

24）雨森宗真著，富士川游他編修 : 松蔭医談/杏林叢 書, 第四輯, p.8, 吐鳳堂書店, 1925

25）山田元倫撰 : 名家方選, 三十九丁裏, 浅井荘右衛 門他, 天明元年

26）難波恒雄著：原色和漢薬図鑑，(上), pp.312-314, 保育社, 1984

27）小野蘭山口授: 本草綱目啓蒙, 巻之十九, 九丁 
表, 林喜兵衛他, 享和三年一文化二年

28）宮崎安貞編録, 貝原楽軒删補 : 農業全書, 巻之二, 四十七丁表, 小川多左衛門, 天明七年

29）寺島良安編：和漢三才困会 (復刻), p.1442, 吉 川弘文館, 1906

30）著者未詳, 塙保已一他編纂 : 料理物語/続群書類
従，第十九輯下，巻第五百六十五／訂正三版， p.368, p.370, 続群書類從完成会, 1957

31）朱丹渓撰: 本草衍義補遺/丹溪医集， p. 77 , 人民 衛生出版社, 1993

32）危亦林編著：世医得効方， p.147, 上海科学技術 出版社, 1991

要旨 薏荝仁は, 往古は不老延寿の薬であった。『黄帝内経素問』には真心脉を薏莰仁に例 えて形態的特徵が記され，また『金實要略』には意荅仁を含む四処方が記載されている。意荝 仁の治疣作用については，『本草綱目』や『能毒』にも記載なく, 江戸時代の治病療法として は艾炎もよく用いられた。薏荝仁の治庞作用を最初に記載した文献は『大和本草』であるとさ れているが，その病変の記述からは疣贅とは即断できない。従来はその後の『松蔭医談』の意 药仁の治疮記載を経て，『青囊瑣探』の治疮神方が最初の治疮処方とされて来た。しかし今回 の独自の調查で『青囊頊探』の 20 年前に, 山田元倫撰『名家方選』に「治病方 薏药三銭甘草 一分」といら内服のみならず外用にも用いる処方の記載を見出した。治病作用の発見は恐らく チョウセンムギの菓子としての摂食よりも薏荝飯, 意荝䉼による大量摂取によって著効例を多 数経験したことによるものではないかと考按した。

キーワード : 薏蔌仁, 治疮処方, 青囊頊探, 名家方選, 薏蔌䉼 